ORIGINAL ARTICLE / ARTIGO ORIGINAL

\title{
Gender differences in disability among older adults in the context of social gender and income inequalities: 2013 Brazilian Health Survey
}

\author{
Diferenças de gênero na incapacidade entre idosos no contexto de \\ desigualdades sociais de gênero e de renda: Pesquisa Nacional de Saúde 2013
}

\author{
André Luiz Barbosa de Lima' (D), Albert Espelt"IIII,IV (iD, Marina Bosque-Prous ${ }^{\mathrm{V}}$ (D), \\ Kenio Costa Limal (iD
}

\begin{abstract}
Objectives: To estimate the magnitude of gender differences in disability among adults aged 60 and older and to evaluate whether they can be associated with social gender inequality and socioeconomic contextual factors at the level of Brazilian federative units. Methods: This is a multilevel study that used data from 23,575 older adults of 27 federative units who participated in the 2013 Brazilian Health Survey. The activity limitation index was developed from the item response theory, using activities of daily living and instrumental activities of daily living variables. The association of individual and contextual variables with disability was estimated by assessing the magnitude of differences between genders, using cross-level interaction effects in multilevel generalized linear models, including only the variables that were statistically significant in the final model. Results: The prevalence of disability was higher among women (37.6\%) than among men $(26.5 \%)$, totaling $32.7 \%$ of the older adults. In the adjusted multilevel analysis, disability was influenced by income inequality $\left(\gamma_{\text {gini }}=0.022, \mathrm{p}<0.001\right)$ among federative units. In addition, gender differences in disability were associated with social gender inequalities $\left(\gamma_{\text {mgixsex }}=0.020, \mathrm{p}=0.004\right)$. Conclusion: Women had higher disability disadvantages compared to men, and those differences were associated with social gender inequalities among the Brazilian federative units influenced by income inequality.
\end{abstract}

Keywords: Health of the Disabled. Aging. Health Status Disparities. Multilevel analysis.

'Department of Dentistry, Universidade Federal do Rio Grande do Norte - Natal (RN), Brazil.

"Facultat de Ciències de la Salut de Manresa, Universitat de Vic Universitat Central de Catalunya (UVicUCC) - Manresa, Spain. "'Department of Psychobiology and Methodology of Health Sciences, Universitat Autònoma de Barcelona - Barcelona, Spain ıventro de Investigación Biomédica en Red de Epidemiología y Salud Pública - Madrid, Spain.

vFaculty of Health Sciences, Universitat Oberta de Catalunya - Barcelona, Spain.

Corresponding author: André Luiz Barbosa de Lima. Universidade Federal do Rio Grande do Norte. Avenida Senador Salgado Filho, 1.787, CEP: 59056-000, Lagoa Nova, Natal, RN, Brazil. E-mail: andreveterinario@hotmail.com

Conflict of interests: nothing to declare - Financial support: Coordination of Superior Level Staff Improvement (CAPES, Process no. 99999.006363/2015-06). 
RESUMO: Objetivos: Estimar a magnitude das diferenças de gênero na incapacidade entre adultos com 60 anos ou mais e avaliar se elas podem estar associadas à desigualdade social de gênero e aos fatores contextuais socioeconômicos no nível das unidades federativas brasileiras. Métodos: Estudo multinível que utilizou dados de 23.575 adultos mais velhos das 27 unidades federativas que participaram da Pesquisa Nacional de Saúde de 2013. O índice de limitação de atividades foi desenvolvido a partir da teoria de resposta ao item, utilizando-se variáveis de atividades básicas e instrumentais da vida diária. Foram estimadas as associações das variáveis individuais e contextuais com a incapacidade, avaliando-se a magnitude das diferenças entre os gêneros, ao utilizar efeitos de interação de nível cruzado em modelos lineares generalizados multiníveis, incluindo-se apenas as variáveis que foram estatisticamente significantes no modelo final. Resultados: A prevalência de incapacidade foi mais elevada entre as mulheres $(37,6 \%)$ do que entre os homens (26,5\%), totalizando $32,7 \%$ dos adultos mais velhos. Na análise multinível ajustada, a incapacidade foi influenciada pela desigualdade de renda $\left(\gamma_{\text {gini }}=0,022, \mathrm{p}<0,001\right)$ entre as unidades federativas. Além disso, as diferenças de gênero na incapacidade foram associadas com as desigualdades sociais de gênero $\left(\gamma_{\text {mgixsex }}=0,020, p=0,004\right)$. Conclusões: As mulheres tiveram desvantagens maiores de incapacidade quando comparadas aos homens, e estas diferenças foram associadas às desigualdades sociais de gênero entre unidades federativas brasileiras, influenciadas pelas desigualdades de renda.

Palavras-chave: Saúde da Pessoa com Incapacidade. Envelhecimento. Disparidades nos Níveis de Saúde. Análise multinível.

\section{INTRODUCTION}

Activity limitations are difficulties an individual may experience performing physical tasks. They are considered negative aspects of functionality and constitute an important part of an individual's disability status ${ }^{1,2}$, which is defined within the context of health as the person's feature directly caused by disease, trauma or other health condition that requires medical care provided in the form of individual treatment by professionals (medical model) ${ }^{2}$. However, a person's disability is also affected by the environmental characteristics of his/ her surroundings (social model) ${ }^{3}$.

It is now argued that, as life expectancy continues to increase around the world, life will mean, on average, a longer period wasted by suffering due to frailty, disability, and age-related illness (e.g., cardiovascular diseases, cancer, diabetes mellitus, osteoporosis, among others $)^{4-6}$. In Brazil, the population pyramid is in the process of contraction, resulting from a constant decrease of fertility rates, from 6.3 children per woman, in 1960, to 1.9 children per woman, in 2010. This is already below the replacement level, set as 2.1 children per woman ${ }^{7}$. At the same time, the epidemiological transition occurs differently from the model experienced by industrialized countries (e.g., Canada, the USA, Spain, Germany, England) and even by other nearby locations, such as Chile, Cuba, and Costa Rica. In Brazil, there is coexistence of old and new health problems, in which despite the predominance of chronic and degenerative diseases, the communicable ones still play an important role. 
In Brazil, social inequalities are prevalent in older adults due to the continuing inequitable distribution of resources among groups living under different socioeconomic conditions ${ }^{9}$. Social inequality plays an important role in the prevalence of disability among older adults ${ }^{10}$, especially among women ${ }^{11}$. It is likely that individuals living in areas with better socioeconomic conditions have greater access to medical goods and services and, consequently, are capable of maintaining good health conditions and functional capacity over time $^{12}$. Those cumulative disadvantages mean that women are more likely than men to become poor and suffer from disabilities at an old age ${ }^{13}$.

In a previous study, $33 \%$ of older Brazilian adults had limitations to perform Activities of Daily Living (ADL) (37\% of women and $27 \%$ of men). In the Northeast, this prevalence affected 39\%, followed by the North and Midwest with 35\% each, the South with $32 \%$ and the Southeast with $29 \%{ }^{14}$. The prevalence of disability is significantly higher among users of the public system (32\%) than those of the private health system $(25 \%)^{15}$. The older adults who lived in Federative Units with higher Gini index were more likely to present higher level of disabilities compared to the older adults who lived in states with lower economic disadvantages ${ }^{12,16}$.

Many important studies provide an overview of the disabilities in Brazilian older adults, including gender differences and their determinants ${ }^{17-21}$. Other previous studies have measured the functionality of older adults in Brazil, where disabilities were associated with demographic (sex, age), socioeconomic (occupation, level of schooling, income), and health factors (chronic diseases) $)^{12,22,23}$. Differently of those previous investigations, this study uses the item response theory to aggregate two dimensions of functionality, i.e. ADL and Instrumental ADL (IADL), in a latent trait and estimate cross-level interaction analysis using multilevel modelling. We can, therefore, estimate the contextual effect (aggregate level) of an ecological exposure on individual risk (individual level). The aims of this study were to estimate the magnitude of gender differences in disability among older adults aged 60 and older in Brazil in 2013 and to examine whether those differences could be associated with social gender inequalities and socioeconomic contextual factors at the level of federative units.

\section{METHODS}

\section{SAMPLE AND DATA COLLECTION}

This was a cross-sectional study based on data from the Brazilian Health Survey 2013 (BNHS) ${ }^{23}$. The BNHS selected 81,187 households randomly, and individuals aged 18 years or older were interviewed. One individual from each household was selected in a complex sampling plan. Thus, 64,348 interviews were collected in the households, resulting in a non-response rate of $8.1 \%{ }^{24}$. In total, 60,202 people participated in individual interviews ${ }^{25}$, in which 23,815 were older adults ${ }^{15}$. A selected population of the 
study was composed by 23,575 older adults aged 60 or older living in 27 Brazilian federative units. Calibrated individual weights were established in order to address participants' non-response and sample attrition ${ }^{26}$. Response rates ranged from $84 \%$ in Pará to $96 \%$ in Bahia. A small number $(1,8 \%)$ of individuals was excluded from the study due to lack of data for individual variables or because they were born with physical, hearing, cognitive, or visual impairments. Considering that the data used in this study are anonymous and available in the public domain, submission to the Ethics Committee was not required in accordance with the recommendations of the National Research Ethics Committee of Brazil ${ }^{27}$.

The National Health Survey is a household-based nationwide survey carried out by the Brazilian Department of Health in partnership with the Brazilian Institute of Geography and Statistics (IBGE). The scope of the survey is to establish the health status and lifestyles of the population - as well as how they look after their health - with regard to access and use of services, preventive actions, continuity of care, and health care financing.

\section{ETHICAL APPROVAL}

This study was exempted from submission to an ethics committee in accordance with the recommendations of the Brazilian National Committee for Ethics in Research, as the data used in this study are anonymous and available in the public domain.

\section{DEPENDENT VARIABLE}

The construct of the activity limitation index (ALI), which is used as a proxy to measure disability, was based on 12 questions in the BNHS. They were divided into two functionality dimensions: ADL (k1, k4, k7, k10, k13, k16 and k19) ${ }^{14}$ and IADL (k22, k25, k28, k31 and $\mathrm{k} 34)^{14}$, but they were united in a single latent trait. The self-reported response categories in ADL were:

- 0 : "no difficulty";

- 1: "has little difficulty";

- 2: "has great difficulty";

- 3: "cannot" perform the activities.

The items related to the IADL were transformed into a dichotomous scale (0: "no difficulty"; 1: "has little difficulty, great difficulty, or cannot") due to the scarce number of responses in some categories. 


\section{INDIVIDUAL INDEPENDENT VARIABLES}

The main individual independent variable was sex. The following individual variables were also included in the analysis: age in years; restriction of usual activities during the last two weeks as a result of health problems (yes, no); self-perceived health (very good or good; fair, poor or very poor); medical health insurance plan (yes, no); participation in organized social activities (yes, no); educational level (illiterate or primary study; secondary or tertiary studies); Brazilian economic classification criteria, adapted and based in the sum of scores (by number of color television, bathroom, car, washing machine, DVD player, refrigerator, microwave), educational level and housekeeper (no $=0$; yes $=4$ ), as proposed by $\mathrm{CCEB}^{28}$. Thus, the social classes were categorized as follows: 0-13 (E and D); 14-50 (A, B and C) (Fiocruz, Rio de Janeiro, 2016, unpublished data).

\section{CONTEXTUAL INDEPENDENT VARIABLES}

The following contextual factors at federative unit level were used as additional independent variables:

- The multidimensional gender inequality index (MGII) for 2010, which is based on six dimensions: education, income, work, politics, reproductive health, and protective factors. The methodological strategy used in the construction of the MGII reproduces the same mathematical procedure adopted by the United Nations Development Programme (UNDP) ${ }^{29}$. The MGII ranges from 0 to 1 ; the closer a score is to 1 , the greater the level of social gender inequality ${ }^{30}$;

- The per capita Gini coefficient for 2013 measures the per capita household income distribution. The measure varies between 0 and 1 , where 0 corresponds to perfect equality and 1 to perfect inequality ${ }^{31}$;

- Gross domestic product (GDP) per capita for 2013 is a proxy for living standards, indicating the levels of economic production of the territory ${ }^{33}$;

- Life expectancy for 2013 reflects the average number of years a newborn can be expected to live. It is a summary measure of mortality as a proxy for improvement in living conditions and population health ${ }^{32}$.

\section{STATISTICAL ANALYSIS}

This study used a hybrid model (generalized partial credit model and two logistic parameters) of item response theory ((2LP)/GPCM IRT) to construct the ALI for each individual respondent. Despite the fact that the $\theta$ scale ranged from $-\infty$ to $+\infty$, it was transformed and restricted in continuous values between 0 (no activity limitation) and 1 (maximum activity 
limitation) for practical purposes, and thus allowing regression for nonnegative positively skewed dependent variable.

The second level of multilevel analysis considered those variables related to federative units, and the evaluation of ALI behavior at first level was seen as a function of the predictor variables for both levels. The coefficients of ALI and gender differences therein, as well as the $95 \%$ confidence intervals $(95 \% \mathrm{CI})$ were estimated for each federative unit. To estimate the association between contextual variables and gender differences in disability, cross-level interaction effects were used in multilevel generalized linear models for non-normal (loglinked GLM Gamma) and zero-inflated (logit-linked GLM Binomial), with robust variance responses. Model I included activity limitation by sex, and there was no control for other individual variables. Model II, level 1, included all the individual and contextual variables; Model III (final) comprised all variables that were statistically significant in the multivariate analysis in model II. Intercept and sex factor were considered to be random effects on all models, fitted using gllamm command, using a statistical significance level of 0.05 . The statistical analysis was performed using STATA 14.1 IC statistical software (Stata Corporation, College Station, TX).

\section{RESULTS}

\section{GENDER DIFFERENCES IN DISABILITY}

Among the 23,575 participants in the sample, 32.7\% (95\%CI 32.1-33.3) presented some difficulty in performing the evaluated activities, with a prevalence of $15.9 \%$ for ADL and $29.7 \%$ for IADL. The prevalence of disability (ADL + IADL) was significantly higher among women $(37.6 \%)$ than in men $(26.5 \%)$, similarly to the case with the average ALI $\left(\mu_{\text {women }}=0.167,95 \%\right.$ CI $0.161-0.173 ; \mu_{\text {men }}=0.119,95 \%$ CI 0.112 $-0.125)$. In addition, older women presented disadvantages in terms of disability in the evaluated variables. More details on the characteristics of the survey participants can be found in Table 1 .

Gender differences in disability were observed in most of the federative units. Figure 1 shows the extent of gender differences in disability for each one. The differences and severity of the disability among women are greater in the North and Northeast regions. The closer the results are to the diagonal line, which represents gender equality, the fewer the differences in disability between men and women. Despite the fact that Maranhão (MA), Amapá (AP), Pará (PA) and São Paulo (SP) had the smallest differences between men and women, AP and PA had worse results than SP, but better than MA. However, Alagoas (AL) presented the greatest difference in disability between men and women, while maintaining a high level of it among the older adults. In this regard, we can extract two extreme models, AL and SP, each of them representing the negative and positive aspects of disability in Brazil. 
Table 1. Description of study variables for men and women aged 60 years or older, 2013 National Brazilian Health Survey $(n=23,575)$.

\begin{tabular}{|l|c|c|c|c|}
\hline \multirow{2}{*}{ Individual variables } & \multicolumn{2}{|c|}{ Men } & \multicolumn{2}{|c|}{ Women } \\
\cline { 2 - 5 } & $\mathrm{n}$ & $\%$ & $\mathrm{n}$ & $\%$ \\
\hline
\end{tabular}

Age group (years)

\begin{tabular}{|l|c|c|c|c|}
\hline 60 to 69 & 6,074 & 58.2 & 7,304 & 55.6 \\
\hline 70 to 79 & 3,132 & 30.0 & 3,868 & 29.5 \\
\hline $80+$ & 1,237 & 11.9 & 1,960 & 14.9 \\
\hline Total & 10,443 & 44.3 & 13,132 & 55.7 \\
\hline
\end{tabular}

Restriction of activities in the last two weeks

\begin{tabular}{|c|c|c|c|c|}
\hline No & 9,449 & 90.5 & 11,481 & 87.4 \\
\hline Yes & 994 & 9.5 & 1,237 & 12.6 \\
\hline Total & 10,443 & 44.3 & 13,132 & 55.7 \\
\hline \multicolumn{5}{|l|}{ Self-perceived health } \\
\hline Very good or good & 4,847 & 46.4 & 5,530 & 42.1 \\
\hline Fair, poor or very poor & 5,596 & 53.6 & 7,602 & 57.9 \\
\hline Total & 10,443 & 44.3 & 13,132 & 55.7 \\
\hline \multicolumn{5}{|l|}{ Social activity participation } \\
\hline Yes & 994 & 90.5 & 1,651 & 87.4 \\
\hline No & 9,449 & 9.5 & 11,481 & 12.6 \\
\hline Total & 10,443 & 44.3 & 13,132 & 55.7 \\
\hline \multicolumn{5}{|l|}{ Health medical insurance } \\
\hline Yes & 1,646 & 15.8 & 2,529 & 19.3 \\
\hline No & 8,797 & 84.2 & 10,603 & 80.7 \\
\hline Total & 10,443 & 44.3 & 13,132 & 55.7 \\
\hline \multicolumn{5}{|l|}{ Educational level } \\
\hline Secondary or tertiary studies & 2,468 & 23.6 & 3,070 & 23.4 \\
\hline None or primary studies & 7,975 & 76.4 & 10,062 & 76.6 \\
\hline Total & 10,443 & 44.3 & 13,132 & 55.7 \\
\hline \multicolumn{5}{|l|}{ BR criteria (economic class) } \\
\hline$A, B, C$ & 8,572 & 82.08 & 10,417 & 79.33 \\
\hline E and D & 1,871 & 17.92 & 2,715 & 20.67 \\
\hline Total & 10,443 & 44.3 & 13,132 & 55.7 \\
\hline \multicolumn{5}{|l|}{ Functional tasks*: } \\
\hline Activities of daily living & 1,425 & 13.7 & 2,315 & 17.6 \\
\hline Instrumental activities of daily living & 2,439 & 23.4 & 4,567 & 34.8 \\
\hline Total & 10,443 & 44.3 & 13,132 & 55.7 \\
\hline
\end{tabular}

*n and percentage of limitation in any activity of daily living (ADL) or instrumental activities of daily living (IADL). 


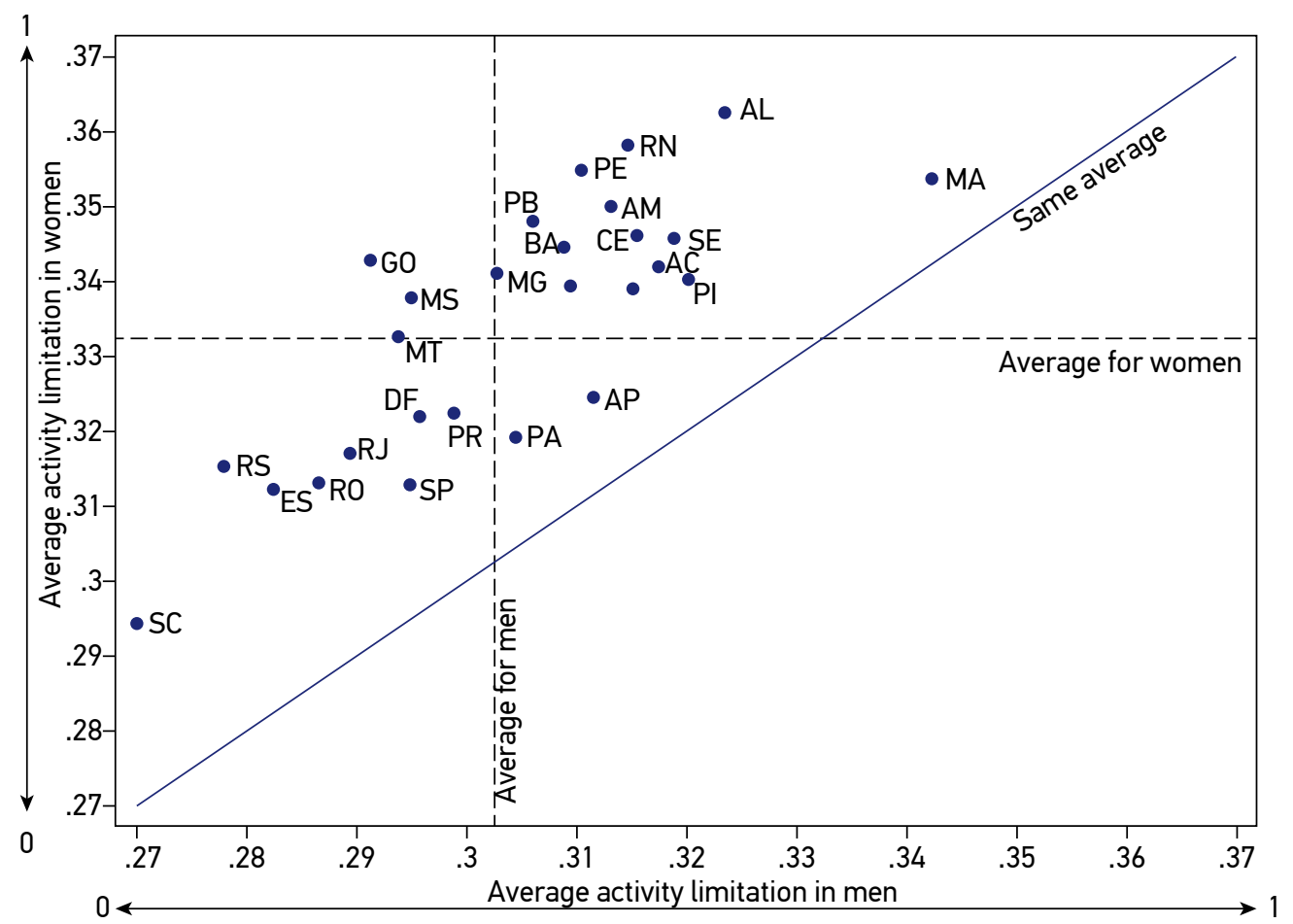

Figure 1. Scatter plot of average activity limitation index among women and men aged 60 or more. Adjusted coefficients of disability in women compared to men, by federative units from the Brazilian Health Survey, Brazil, 2013.

\section{GENDER DIFFERENCES IN DISABILITY AND CONTEXTUAL VARIABLES}

In the first model, disability was significantly higher among women aged 60 or older $\left(\gamma_{\text {women }}=0.050, \mathrm{p}<0.001\right)$ when compared to men, as shown in Table 2 . In an adjusted multilevel analysis (Model III), more advanced age, activity restrictions in the last two weeks prior to the survey, a health-self-perceived as "fair, poor or very poor" and being illiterate or having primary studies are factors associated with greater disability among older adults. On the other hand, social activity participation was associated with lower disability. Those functional disabilities were shown to be significantly influenced by income inequality in all federative units $\left(\gamma_{\text {gini }}=0.022, \mathrm{p}<0.001\right)$. Thus, income inequality has a negative impact on disability in older adults. The best model, in the end, was able to explain $61 \%$ of the differences between the federative units with the social gender inequalities. The differences in disability between men and women were increased when adjusted for the other variables $\left(\gamma_{\text {mgiixsex }}=0.020\right.$, $\mathrm{p}=0.004)$. 
Table 2. Activity limitation index coefficients estimated using multilevel generalized linear models for non-normal response: a sample of Brazilian residents aged 60 or older from 27 federative units participating in the Brazilian Health Survey, 2013.

\begin{tabular}{|c|c|c|c|c|c|c|}
\hline & \multicolumn{2}{|c|}{ Model I } & \multicolumn{2}{|c|}{ Model II } & \multicolumn{2}{|c|}{ Model III } \\
\hline & $\begin{array}{c}\text { Coefficient } \\
\text { (SE) }\end{array}$ & $\mathrm{p}$ & $\begin{array}{l}\text { Coefficient } \\
\text { (SE) }\end{array}$ & $\mathrm{p}$ & $\begin{array}{l}\text { Coefficient } \\
\text { (SE) }\end{array}$ & $\mathrm{p}$ \\
\hline \multicolumn{7}{|l|}{ Individual variables } \\
\hline \multicolumn{7}{|l|}{ Sex (Men) } \\
\hline Women & $\begin{array}{c}0.050 \\
(0.012)\end{array}$ & $<0.001$ & $\begin{array}{l}0.043 \\
(0.008)\end{array}$ & $<0.001$ & $\begin{array}{c}0.045 \\
(0.009)\end{array}$ & $<0.001$ \\
\hline \multicolumn{7}{|l|}{ Age group (60 to 69 years) } \\
\hline 70 to 79 & & & $\begin{array}{l}0.133 \\
(0.008)\end{array}$ & $<0.001$ & $\begin{array}{l}0.132 \\
(0.008)\end{array}$ & $<0.001$ \\
\hline $80+$ & & & $\begin{array}{l}0.339 \\
(0.017)\end{array}$ & $<0.001$ & $\begin{array}{l}0.337 \\
(0.015)\end{array}$ & $<0.001$ \\
\hline \multicolumn{7}{|c|}{$\begin{array}{l}\text { Restriction of activities in the } \\
\text { last two weeks (Yes) }\end{array}$} \\
\hline No & & & $\begin{array}{l}0.216 \\
(0.015)\end{array}$ & $<0.001$ & $\begin{array}{l}0.216 \\
(0.015)\end{array}$ & $<0.001$ \\
\hline \multicolumn{7}{|l|}{$\begin{array}{l}\text { Self-perceived health (Very } \\
\text { good or good) }\end{array}$} \\
\hline Fair, poor or very poor & & & $\begin{array}{l}0.159 \\
(0.018)\end{array}$ & $<0.001$ & $\begin{array}{l}0.161 \\
(0.019)\end{array}$ & $<0.001$ \\
\hline \multicolumn{7}{|c|}{ Social activity participation (No) } \\
\hline Yes & & & $\begin{array}{l}-0.110 \\
(0.012)\end{array}$ & $<0.001$ & $\begin{array}{l}-0.110 \\
(0.011)\end{array}$ & $<0.001$ \\
\hline \multicolumn{7}{|c|}{ Health medical insurance (No) } \\
\hline Yes & & & $\begin{array}{l}-0.018 \\
(0.018)\end{array}$ & 0.306 & & \\
\hline \multicolumn{7}{|c|}{$\begin{array}{l}\text { Educational level (Secondary or } \\
\text { tertiary studies) }\end{array}$} \\
\hline None or primary study & & & $\begin{array}{l}0.076 \\
(0.015)\end{array}$ & $<0.001$ & $\begin{array}{l}0.083 \\
(0.016)\end{array}$ & $<0.001$ \\
\hline \multicolumn{7}{|l|}{$\begin{array}{l}\text { BR criteria (A, B, C economic } \\
\text { class) }\end{array}$} \\
\hline$E$ and $D$ economic class & & & $\begin{array}{c}0.013 \\
(0.013)\end{array}$ & 0.337 & & \\
\hline
\end{tabular}


Table 2. Continuation.

\begin{tabular}{|c|c|c|c|c|c|c|}
\hline & \multicolumn{2}{|c|}{ Model I } & \multicolumn{2}{|c|}{ Model II } & \multicolumn{2}{|c|}{ Model III } \\
\hline & $\begin{array}{l}\text { Coefficient } \\
\text { (SE) }\end{array}$ & $p$ & $\begin{array}{l}\text { Coefficient } \\
\text { (SE) }\end{array}$ & $p$ & $\begin{array}{c}\text { Coefficient } \\
\text { (SE) }\end{array}$ & $p$ \\
\hline \multicolumn{7}{|l|}{ Contextual variables (intercept) } \\
\hline MGII & & & $\begin{array}{c}0.004 \\
(0.013)\end{array}$ & 0.764 & & \\
\hline Gini & & & $\begin{array}{c}0.021 \\
(0.010)\end{array}$ & 0.028 & $\begin{array}{c}0.022 \\
(0.004)\end{array}$ & $<0.001$ \\
\hline GDP & & & $\begin{array}{l}-0.006 \\
(0.012)\end{array}$ & 0.640 & & \\
\hline Life expectancy & & & $\begin{array}{c}0.001 \\
(0.014)\end{array}$ & 0.983 & & \\
\hline \multicolumn{7}{|l|}{$\begin{array}{l}\text { Contextual variables } \\
\text { (interaction with sex) }\end{array}$} \\
\hline MGII & & & $\begin{array}{c}0.015 \\
(0.007)\end{array}$ & 0.024 & $\begin{array}{c}0.020 \\
(0.007)\end{array}$ & 0.004 \\
\hline Gini & & & $\begin{array}{c}0.004 \\
(0.010)\end{array}$ & 0.692 & & \\
\hline GDP & & & $\begin{array}{l}-0.021 \\
(0.013)\end{array}$ & 0.092 & & \\
\hline Life expectancy & & & $\begin{array}{c}0.021 \\
(0.014)\end{array}$ & 0.132 & & \\
\hline Intercept & $\begin{array}{l}-0.878 \\
(0.013)\end{array}$ & $<0.001$ & $\begin{array}{l}-1.232 \\
(0.026)\end{array}$ & $<0.001$ & $\begin{array}{l}-1.238 \\
(0.030)\end{array}$ & $<0.001$ \\
\hline \multicolumn{7}{|l|}{ Variability } \\
\hline $\begin{array}{l}\text { Intercept variability (\% of } \\
\text { change }^{*} \text { ) }\end{array}$ & 0.253 & & & & $\begin{array}{l}0.063 \\
(75 \%)\end{array}$ & \\
\hline $\begin{array}{l}\text { Interaction with sex ( } \% \text { of } \\
\text { change*) }\end{array}$ & 0.137 & & & & $\begin{array}{l}0.053 \\
(61 \%)\end{array}$ & \\
\hline
\end{tabular}

\section{DISCUSSION}

Results showed that the limitations in IADL were more prevalent than the ADL among older adults. This can be explained because the ability to perform the IADL is primarily affected, especially because it requires greater motor and cognitive skills, which tend to be lost early in the aging process ${ }^{33-35}$. 
The participation of older adults in community activities and the restriction in the performance of activities in the last two weeks have a direct relationship with one another, pointing out an evaluation of the quality of social life among older adults towards the disability consequences. The participation in community activities is related to the control of the physical and social environment, reflecting better functioning and cognitive skills of older adults ${ }^{36}$.

The disabilities associated with self-perceived health status among older adults were consistent with other findings in previous research ${ }^{12,16}$. Hence, it has been suggested that 'poor' self-perceived health among women is a reflection of the higher burden of diseases they suffer. However, when this burden of diseases was compensated, the gender gap disappeared ${ }^{37}$.

Another finding was that the subscription to a health insurance was not associated with disability. It is likely that, in line with the theory of lack of information asymmetry, there is little significance in health condition variables that explain the private ownership status among older adults ${ }^{38-40}$. However, a Brazilian study showed that older adults who were enrolled in a health insurance had lower probability of high level of difficulty in accomplishing the ADL compared to those who did not have a health insurance ${ }^{12}$.

Regarding education and income, as the levels increase, the probability of the older adults to be able to perform ADL increase ${ }^{12}$. Low educational level has a direct association with greater disabilities among the older adults, compromising access to health education, which is a strategy that allows the adoption of healthy behaviors and social mobilization to improve living conditions ${ }^{41}$. Among older women, education seems to be associated with better functional capacity ${ }^{42}$.

\section{GENDER DIFFERENCES IN DISABILITY}

Similar to other studies ${ }^{10,12,16}$, disability was found to be worse among women in all the federative units. The high prevalence of disability in women is due to a combination of high incidence and long duration of disability, resulting from lower rates of rehabilitation and mortality among women with functional disability ${ }^{43}$. Gender may be a risk factor for explaining a worse physical function among women, but moving to equity could attenuate gender gaps in the physical function with advanced age ${ }^{13,44}$. According to BNHS data, all Brazilian regions showed similar levels of disability to the national average, with no differences between men and women ${ }^{34}$.

Two models of gender differences in disability can be highlighted: AL, with a high level of disability among older adults and a large disadvantage of women versus men, which is above the national average in both cases; and SP, with a low level of disability among older adults and a few differences between men and women, which is below the national average for both. Alagoas and São Paulo represent the socioeconomic extremes among the Brazilian federative units. In addition to the low level of human development, AL cannot meet the 
needs of the current generations without compromising the capacity of reaching the needs of future generations, due to the low sustainability. Therefore, urgent state interventions are demanded ${ }^{45,46}$. It is noteworthy that SP, besides the socioeconomic advantages that it presents ahead of many other federative units, is considered an "older adults friendly state". In practical terms, SP adapts its structures and services to be accessible and inclusive to the older adults with varying needs and capacities ${ }^{47}$.

Therefore, SP is an example in which intersectoriality happens in policies directed towards older adults. The other federative units should see SP as a positive model, although not ideal, and replicate intersectoral policies with the aim of improving the older adult population's life $\mathrm{e}^{48}$. Thus, it is necessary to provide active and healthy aging, applying and implementing health information and education strategies, focusing on the prevention of disabilities and their determinants, going beyond prescriptive methodologies and placing older adults as transforming subjects of their reality.

\section{GENDER DIFFERENCES IN DISABILITY AND CONTEXTUAL FACTORS}

\section{Social gender inequalities}

In Brazil, the highest rates of social gender inequality were associated with higher gender differences in disability, with women at a greater disadvantage ${ }^{16}$. A previous study found that the greatest social gender inequalities in federative units seem to be associated with high incidence of long-term disability among older women ${ }^{43}$. In fact, gender differences in disability may be related to broader social gender inequalities, raising questions on how health, socioeconomic, and cultural factors influence gender patterns of seeking and using health care in later life in the country ${ }^{49,50}$.

\section{Socioeconomic contextual factors}

Income inequality is a main contextual factor in the social environment, and it affects directly health, increasing the probability of older adults presenting functional disability ${ }^{12}$. Therefore, income inequality deepens gender inequality and disadvantages for older women that have a history of low participation in the labor market, have minimal retirement benefits and depend on the public health system ${ }^{41}$. With lower incomes than men, women have less access to health and education that can ensure an improvement in their health quality, since highly educated women were more than 10 times as likely to age successfully as were women with low levels of education ${ }^{10,42}$.

In addition, it is noteworthy that disability is strongly associated with chronic disease, and functional disability relates to the performance of physical activities and social participation $^{51}$. Therefore, prevention policies (for example, those that combat chronic disease) 
can help to delay the processes that lead to disability in older adults ${ }^{52}$. As in this study, other manuscripts did not find the GDP effect of disability on older adults in Brazil ${ }^{12,16}$. As for life expectancy, there was no effect either, even though it is an important indicator of the population's quality of life. It has also demonstrated the negative impact of disability on the health of older adults and its differential effects on women, considering their higher disabled life expectancy ${ }^{18}$. Other studies could be conducted by adding new individual and contextual variables, including the disability-free life expectancy, and making a comparison with other countries.

\section{STRENGTHS AND LIMITATIONS}

This study provides a representative approach to self-reported functional performance of older Brazilians and contributes to the analysis of the health situation in Brazil, allowing researchers to trace the disability profile in Brazil. It also reinforces the importance of policies that reduce social inequalities in disability. Despite this, this study has some limitations. The response rates were lower in some federative units compared to others, although sample weights have been used to correct this. Another limitation is derived from the nature of the sample: information was only collected from older adults living in the community and excluded other living situations, such as nursing homes, convents, and hospitals ${ }^{34}$. Moreover, the database that represents the general population, has limitations, particularly because it addressed self-reported diagnosis data ${ }^{53}$. Older adults, at a disadvantaged socioeconomic level, might not have understood the questions asked during the BNHS or might be unaware of certain problems assessed in their locality, underestimating the prevalence. Furthermore, the study consisted of 27 samples in the second level of analysis, which could limit the ability to detect statistically significant differences between groups.

\section{CONCLUSIONS}

Women had higher disability disadvantages compared to men, and those differences were associated with social gender inequalities among the Brazilian federative units influenced by income inequality. However, it is important to consider that more studies are needed to elucidate other dimensions of functionality within and between the federative units, considering other social determinants of health.

\section{ACKNOWLEDGMENTS}

This article is part of the doctoral thesis of André Luiz Barbosa Lima, of the Federal University of Rio Grande do Norte, Brazil, with support from the Public Health Agency of Barcelona, Spain. 


\section{REFERENCES}

1. Stineman MG, Henry-Sánchez JT, Kurichi JE, Pan Q, Xie D, Saliba D, et al. Staging activity limitation and participation restriction in elderly community-dwelling persons according to difficulties in self-care and domestic life functioning. Am J Phys Med Rehabil 2012; 91(2): 12640. http: / / doi.org/10.1097/PHM.0b013e318241200d

2. World Health Organization. International Classification of Functioning, Disability and Health (ICF). Geneva: World Health Organization, 2001.

3. Sadana R, Blas E, Budhwani S, Koller T, Paraje G. Healthy ageing: Raising awareness of inequalities, determinants, and what could be done to improve health equity. Gerontologist 2016; 56(Suppl. 2): S17893. http:/ / doi.org/10.1093/geront/ gnw034

4. Kirkwood TBL. Healthy old age. Nature 2008; 455 : 739-40. http: / / doi.org/10.1038/455739a

5. Veras RP. Estratégias para o enfrentamento das doenças crônicas: um modelo em que todos ganham [Strategies for coping with chronic diseases: a model where everyone wins]. Rev Bras Geriatr e Gerontol 2011; 14(4): 779-86. http:/ / doi.org/10.1590/S1809-98232011000400017

6. Jaul E, Barron J. Age-Related Diseases and Clinical and Public Health Implications for the 85 Years Old and Over Population. Front Public Health 2017; 5: 335. http: / / doi.org/10.3389/fpubh.2017.00335

7. AndersonJSN, SchneiderS. Brazilian Demographic Transition and the Strategic Role of Youth. Espace populations sociétés 2014; (2-3). http:// doi.org/10.4000/eps.5774

8. Schramm JMA, Oliveira AF, Leite IC, Valente JG, Gadelha AMJ, Portela MC, et al. Transição epidemiológica e o estudo de carga de doença no Brasil [Epidemiological transition and the study of burden of disease in Brazil]. Ciên Saúde Colet 2004; 9(4): 897-908. http:/ / doi. org/10.1590/S1413-81232004000400011

9. Braga LS, Lima-Costa MF, César CC, Macinko J. Social inequalities on selected determinants of active aging and health status indicators in a large Brazilian city (2003-2010). J Aging Health 2016; 28(1): 180-96. http:// doi.org/10.1177/0898264315589575

10. Melzer D, Parahyba MI. Socio-demographic correlates of mobility disability in older Brazilians: Results of the first national survey. Age Ageing 2004; 33(3): 2539. http:/ / doi.org/10.1093/ageing/afh075

11. World Health Organization. Active ageing: A policy framework. A contribution of the World Health Organization to the Second United Nations World Assembly on Ageing, Madrid, Spain, 2002 [Internet]. Geneva: World Health Organization; 2002 [cited on June 13, 2018]. Available from: https: / / extranet.who.int/agefriendlyworld/wp-content/ uploads/2014/06/WHO-Active-Ageing-Framework.pdf
12. Alves LC, Leite IC, Machado CJ. Factors associated with functional disability of elderly in Brazil: A multilevel analysis. Rev Saúde Pública 2010; 44(3): 468-78. http: / / doi.org/10.1590/S0034-89102010005000009

13. Zunzunegui MV, Alvarado BE, Guerra R, Gómez JF, Ylli A, Guralnik JM, et al. The mobility gap between older men and women: The embodiment of gender. Arch Gerontol Geriatr 2015; 61(2): 140-8. http:/ / doi. org/10.1016/j.archger.2015.06.005

14. Instituto Brasileirode Geografiae Estatística. Pesquisa Nacional de Saúde [Health National Survey] 2013, Brazil [Internet]. Rio de Janeiro: Instituto Brasileiro de Geografia e Estatística [Brazilian Institute of Geography and Statistics]; 2013 [cited on February 15, 2018]. Available from: https:/ / www.pns. icict.fiocruz.br/arquivos/Novos/Questionario\%20PNS.pdf

15. Silva AMM, Mambrini DM, Peixoto SV, Malta DC, Lima-Costa MF. Uso de serviços de saúde por idosos brasileiros com e sem limitação funcional [Use of health services by Brazilian elderly with and without functional limitation]. Rev Saúde Pública 2017; 51(Suppl. 1): 5s. http: / / doi.org/10.1590/s1518-8787.2017051000243

16. Lima ALB, Lima KC. Activity limitation in the elderly people and inequalities in Brazil. Open Access Library Journal 2014; 1: e739. http://doi.org/10.4236/oalib.1100739

17. Barbosa AR, Souza JMP, Lebrão ML, Laurenti R, Marucci MFN. Functional limitations of Brazilian elderly by age and gender differences: Data from SABE survey. Cad Saúde Pública 2005; 21(4): 1177-85. http:/ / doi.org/10.1590/S0102-311X2005000400020

18. Andrade FCD, Guevara PE, Lebrão ML, Duarte YAO, Santos JLF. Gender differences in life expectancy and disability-free life expectancy among older adults in Sao Paulo, Brazil. Womens Health Issues 2011; 21(1): 64-70. http:// doi.org/10.1016/j.whi.2010.08.007

19. Alexandre T, Corona LP, Nunes DP, Santos JLF, de Oliveira Duarte YA, Lebrão ML. Gender differencesin incidence and determinants of disability in activities of daily living among elderly individuals: SABE study. Arch Gerontol Geriatr 2012; 55(2): 431-7. http:// doi.org/10.1016/j.archger.2012.04.001

20. Campos ACV, Albala C, Lera L, Sánchez H, Vargas AMD, Ferreira e Ferreira F. Gender differences in predictors of self-rated health among older adults in Brazil and Chile. BMC Public Health 2015; 15: 36576. http: / / doi.org/10.1186/s12889-015-1666-9

21. Lima-Costa MF, Mambrini JVM, Peixoto SV, Malta DC, Macinko J. Socioeconomic inequalities in activities of daily living limitations and in the provision of informal and formal care for noninstitutionalized older Brazilians: National Health Survey. Int J Equity Health 2016; 15 : 137-45. http: / / doi.org/10.1186/s12939-016-0429-2 
22. Beltrão KI, Teixeira MP, Parahyba MI, Fletcher P. Capacidade funcional dos idosos: Uma análise dos suplementos Saúde da PNAD com a teoria de resposta ao item [Functional capacity of the elderly: An analysis of the PNAD Health supplements with the item response theory] [Internet]. Rio de Janeiro: Instituto Brasileiro de Geografia e Estatística [Brazilian Institute of Geography and Statistics]; 2013 [cited on July 21, 2018]. Available from: http:/ / biblioteca.ibge.gov.br/ visualizacao/livros/liv65318.pdf

23. Szwarcwald CL, Malta DC, Pereira CA, Vieira MLFP, Conde WL, Souza-Júnior PRBD, et al. Pesquisa Nacional de Saúde no Brasil: concepção e metodologia de aplicação [National Health Survey in Brazil: design and methodology of application]. Ciênc Saúde Coletiva [Science and Collective Health] 2014; 19(2): 333-42. http:/ / doi.org/10.1590/1413-81232014192.14072012

24. Claro RM, Santos MAS, Oliveira TP, Pereira CA, Szwarcwald CL, Malta DC. Unhealthy food consumption related to chronic noncommunicable diseases in Brazil: National Health Survey, 2013. Epidemiol Serv Saúde 2015; 24(2): 257-65. http:/ / doi.org/10.5123/S1679-49742015000200008

25. Souza-Júnior PRB, Freitas MPS, Antonaci GA, Szwarcwald CL. Sampling Design for the National Health Survey, Brazil 2013. Epidemiol Serv Saúde 2015; 24(2): 207-16. http: / / doi.org/10.5123/S1679-49742015000200003

26. Instituto Brasileiro de Geografia e Estatística. Pesquisa Nacional de Saúde: Percepção de estado de saúde, estilo de vida e doenças crônicas [National Health Survey: Perception of health status, lifestyle and chronic diseases], Brazil [Internet]. Rio de Janeiro: Instituto Brasileiro de Geografia e Estatística [Brazilian Institute of Geography and Statistics]; 2014 [cited on July 12, 2018]. [181 p.]. Available from: http://biblioteca.ibge. gov.br/visualizacao/livros/liv91110.pdf

27. Brazil. Conselho Nacional de Saúde [Health National Council]. Resolução [Resolution] n ${ }^{\circ}$ 510, April 7, 2016 [Internet]. Brazil: Conselho Nacional de Saúde; 2016 [cited on July 12, 2018]. Available from: http:/ / conselho.saude.gov.br/resolucoes/2016/Reso510.pdf

28. Associação Brasileira de Empresas de Pesquisa [Research Companies Brazilian Association]. Critério de Classificação Econômica Brasil [Brazil Economic Classification Criteria] 2008 [Internet]. Brazil: Associação Brasileira de Empresas de Pesquisa; 2008 [cited on July 12, 2018]. Available from: http:/ / www. abep.org/Servicos / Download.aspx?id=05

29. KlugmanJ.HumanDevelopment Report 2011. Sustainability and Equity: A better future for all [Internet]. UNDP-HDRO Human Development Reports; 2011 [cited on August 10, 2018]. Available from: http:/ / hdr.undp.org/sites/default / files/reports/271/hdr_2011_en_complete.pdf
30. Lima PVPS, Sousa MR, Khan AS, Rocha LA. Distribuição espacial da desigualdade de gênero no Brasil [Spatial distribution of gender inequality in Brazil]. INTERthesis 2015; 12(1): 292-320. http: / / doi. org/10.5007/1807-1384.2015v12n1p292

31. Brazil. Ministry of Health. Indicators and Basic Data - IDB, Inter-Agency Health Information Network - RIPSA [Internet]. Brasilia: RIPSA; 2013 [cited on September 02, 2018]. Available from: http: / / tabnet2. datasus.gov.br/cgi/idb2013/matriz.htm

32. Brazil. Ministry of Health. DATASUS [Internet]. Brasília: TABNET; 2013 [cited on April 21, 2018]. Available from: http:/ / datasus.saude.gov.br/

33. Bosco R de M, Assis EPS, Pinheiro RR, Queiroz LCV de, Pereira LSM, Antunes CMF. Anemia and functional capacity in elderly Brazilian hospitalized patients. Cad Saúde Pública 2013; 29(7): 1322-32. http:/ / doi. org/10.1590/S0102-311X2013000700007

34. Instituto Brasileiro de Geografia e Estatística. Pesquisa Nacional de Saúde: Ciclos de vida [National Health Survey: Life Cycles], Brazil [Internet]. Rio de Janeiro: Instituto Brasileiro de Geografia e Estatística [Brazilian Institute of Geography and Statistics]; 2013 [cited on April 15, 2018]. [p. 30-5]. Available from: http://biblioteca. ibge.gov.br/visualizacao/livros/liv94522.pdf

35. Wu C-Y, Hu H-Y, Li C-P, Fang Y-T, Huang N, Chou Y-J. The association between functional disability and acute care utilization among the elderly in Taiwan. Arch Gerontol Geriatr 2013; 57(2): 177-83. http: / / doi. org/10.1016/j.archger.2013.04.011

36. Dias EG, Duarte YAO, Almeida MHM, Lebrão ML. Caracterização das atividades avançadas de vida diária (AAVDS): um estudo de revisão [Characterization of advanced activities of daily living (AADL): a review]. Rev Ter Ocup da Univ São Paulo 2011; 22(1): 45-51. http:/ / doi.org/10.11606/issn.2238-6149.v22i1p45-51

37. Malmusi D, Artazcoz L, Benach J, Borrell C. Perception or real illness? How chronic conditions contribute to gender inequalities in self-rated health. EurJ Public Health 2012; 22(6): 781-6. http:/ / doi.org/10.1093/eurpub/ckr184

38. Hernandes ESC, Lebrão ML, Duarte YAO, Santos JLF. Idosos com e sem plano de saúde e características socioepidemiológicas associadas [Health insurance coverage of the elderly and socioepidemiological characteristics associated]. Rev Saúde Pública 2012; 46(6): 1030-8. http://doi.org/10.1590/ S0034-89102012000600013

39. Bós AMG, Bós ÂJG. Determinantes na escolha entre atendimento de saúde privada e pública por idosos [Determinants of elders' choice between private and public health care providers]. Rev Saúde Pública. 2004; 38(1): 113-20. http: / / doi.org/10.1590/ S0034-89102004000100016 
40. Lima e Costa MF, Uchoa E, Guerra HL, FirmoJO, Vidigal PG, Barreto SM. The Bambuí health and ageing study (BHAS): methodological approach and preliminary results of a population-based cohort study of the elderly in Brazil. Rev Saúde Pública. 2000; 34(2): 97-103. http: / / doi.org/10.1590/S0034-89102000000200005

41. Geib LTC. Social determinants of health in the elderly. Ciênc Saúde Coletiva [Science \& Collective Health] 2012; 17(1): 123-33. http:/ / doi.org/10.1590/ S1413-81232012000100015

42. Park SM, Jang SN, Kim DH. Gender differences as factors in successful ageing: A focus on socioeconomic status. J Biosoc Sci 2010; 42(1): 99-111. http:// doi. org/10.1017/S0021932009990204

43. Hardy SE, Allore HG, Guo Z, Gill TM. Explaining the effect of gender on functional transitions in older persons. Gerontology 2008; 54(2): 79-86. http:// doi. org/10.1159/000115004

44. Leveille SG, Penninx BW, Melzer D, Izmirlian G, Guralnik JM. Sex differences in the prevalence of mobility disability in old age: the dynamics of incidence, recovery, and mortality. J Gerontol B Psychol Sci Soc Sci 2000; 55(1): 41-50. http:/ / doi.org/10.1093/geronb/55.1.S41

45. Alves DB, Barbosa MTS. Desigualdades na mortalidade por doenças crônicas entre idosos e sua associação com indicadores socioeconômicos no Brasil [Inequalities in mortality due to chronic diseases among the older adults and their association with socioeconomic indicators in Brazil]. Rev Bras Ciênc Envelhec Hum 2011; 7(1): 22-33. https: / / doi.org/10.5335/rbceh.2012.263

46. Macedo MAS, Ferreira AFR, Cípola FC. Análise do nível de sustentabilidade das Unidades Federativas do Brasil e de suas capitais: um estudo sob as perspectivas econômica, social e ambiental [Analysis of the sustainability level of the Brazilian Federative Units and its capitals: a study under the economic, social and environmental perspectives]. Rev Gestão Soc e Ambient 2011; 5(3): 73-89. http://doi.org/10.24857/rgsa.v5i3.341

47. Gragnolati M, Jorgensen OH, Rocha R, Fruttero A. Growing Old in an Older Brazil: Implications of Population Aging on Growth, Poverty, Public Finance and Service Delivery. Washington, D.C.: The World Bank; 2011. 299 p. http: / / doi.org/10.1596/978-0-8213-8803-7
48. Oliveira AD, Ramos OA, Panhoca I, Alves VLS. A intersetorialidade nas políticas públicas para $\mathrm{O}$ envelhecimento no Brasil [The intersectoriality in public policies for aging in Brazil]. Rev Kairós Gerontol [Internet] 2014 [cited on July 5, 2018]; 17(2): 91-103. Available from: https: / revistas.pucsp.br/index.php/ kairos/article/view/21278/15556

49. Espelt, A, Font-Ribera L, Rodriguez-Sanz M, Artazcoz L, Ferrando J, Plaza A, et al. Disability among older people in a southern European city in 2006: Trends in gender and socioeconomic inequalities. J Womens Health 2010; 19(5): 927-33. http:/ / doi.org/10.1089/ jwh.2009.1608

50. Barreto SM, Giatti L, Kalache A. Gender inequalities in health among older Brazilian adults. Rev Panam Salud Publica 2004; 16(2): 110-17. http:/ / doi.org/10.1590/ S1020-49892004000800006

51. Loke SC, Lim WS, Someya Y, Hamid TA, Nudin SS. Examining the disability model from the international classification of functioning, disability, and health using a large data set of community-dwelling Malaysian older adults. J Aging Health 2016; 28(4): 704-25. http: / / doi. org/10.1177/0898264315609907

52. McGough EL, Zumsteg JM. Lifestyle changes in the prevention of mobility disability. Healthy Aging Clin Care Elder 2014; 6: 33-41. http://doi.org/10.4137/ HACCE.S12502

53. Malta DC, Bernal RTI, Lima MG, Araújo SSC, Silva MMA, Freitas MIF, et al. Noncommunicable diseases and the use of health services: analysis of the National Health Survey in Brazil. Rev Saúde Pública 2017; 51(Suppl. 1): 1-10. http://doi.org/10.1590/ s1518-8787.2017051000090

\author{
Received on: 07/12/18 \\ Accepted on: 11/25/2018 \\ Approved on: 01/10/2019
}

Authors' contributions: André Luiz Barbosa de Lima, Albert Espelt and Kenio Costa Lima participated in all stages of the research; Marina Bosque-Prous drafted the work and revised it critically for important intellectual content. 